\title{
Corn grain and liquid feed as nonfiber carbohydrate sources in diets for lactating dairy cows ${ }^{1}$
}

\author{
M. L. Eastridge, ${ }^{2}$ A. H. Lefeld, A. M. Eilenfeld, P. N. Gott, W. S. Bowen, and J. L. Firkins \\ Department of Animal Sciences, The Ohio State University, Columbus 43210
}

\begin{abstract}
Interactions of sources and processing methods for nonstructural carbohydrates may affect the efficiency of animal production. Five rumen-cannulated cows in late lactation were placed in a $5 \times 5$ Latin square design and fed experimental diets for $2 \mathrm{wk}$. In the production trial, 54 cows were fed the experimental diets for $12 \mathrm{wk}$ beginning at d 60 in milk. Diets contained $24 \%$ corn silage and $22 \%$ hay, averaging $20 \%$ alfalfa and $2 \%$ grass but being adjusted as needed to maintain dietary concentrations of $36 \%$ neutral detergent fiber. The control diet contained steam-flaked corn (SFC) and the other diets contained either finely (FGC; $0.8 \mathrm{~mm}$ ) or coarsely ground corn (CGC; $1.9 \mathrm{~mm}$ ), factorialized with or without $3.5 \%$ liquid feed (LF). The LF diets provided $1.03 \%$ of dietary dry matter as supplemental sugar. The FGC decreased rumen $\mathrm{pH}$ and concentration of $\mathrm{NH}_{3} \mathrm{~N}$ compared with CGC. The SFC and FGC tended to increase the molar percentage of ruminal propionate and decrease the acetate:propionate ratio. The LF increased molar percentage of ruminal butyrate with FGC but not CGC. The LF tended to decrease starch digestibility with the CGC but not with the FGC. As expected, the SFC and FGC increased total tract starch digestibility. The DMI and milk yield were similar among dietary treatments. Compared with ground corn diets, the SFC tended to decrease milk fat percentage; thus, $3.5 \%$ fatcorrected milk and feed efficiency were decreased with SFC. The LF decreased milk protein percentage but had no effect on milk protein yield. The SFC compared with dry ground corn decreased the concentration of milk urea nitrogen. Sugar supplementation using LF appeared to be more beneficial with FGC than CGC. Increasing the surface area by finely grinding corn is important for starch digestibility and optimal utilization of nutrients.
\end{abstract}

\footnotetext{
Received October 7, 2010

Accepted February 21, 2011.

${ }^{1}$ Research was supported by state and federal funds appropriated to the Ohio Agricultural and Development Center, The Ohio State University. Manuscript number 18/10AS. Additional support was provided by Quality Liquid Feeds, Dodgeville, WI.

${ }^{2}$ Corresponding author: Eastridge.1@osu.edu
}

Key words: starch, sugars, grain particle size, corn processing

\section{INTRODUCTION}

Ruminal and total tract digestibilities and animal responses to steam flaking, steam rolling, dry rolling, and grinding of cereal grains differ (Firkins et al., 2001). Decreasing the mean particle size of dry corn from 4.8 to 2.6 to $1.2 \mathrm{~mm}$ when fed to lactating cows increased ruminal and total tract digestibility of NSC and tended to cause a slight shift in NDF digestion to the hindgut (Callison et al., 2001). In this same study, decreasing the particle size of the grain increased the rate of NSC digestion in the rumen and the $1.2 \mathrm{~mm}$ particle size decreased ruminal $\mathrm{pH}$ compared with the $2.6 \mathrm{~mm}$ particle size, but milk fat percentage and yield were not affected. In a review of corn processing, Firkins et al. (2001) noted that increased NSC digestibility corresponded with decreased NDF digestibility in the rumen. Thus, an optimal amount of rumen-degraded starch should maximize the total digestibility of carbohydrate (NSC plus NDF).

Replacing a portion of the starch in the diet with sucrose $(0,2.5,5.0$, and $7.5 \%)$ was shown to linearly increase DMI and milk fat percentage and yield (Broderick et al., 2008). Yet, feed efficiency was not affected by sugar addition. Broderick and Radloff (2004) suggested $5 \%$ total sugar or $2.4 \%$ added sugar from molasses as optimal for lactating cows based on DMI and yield of milk and milk components. Using liquid feed (LF) containing cane molasses and corn steep liquor, Firkins et al. (2008) observed a 5\% numerical increase in DMI and an increase in milk fat yield when $1.7 \%$ sugar was added in diets (6.3\% total sugar) with 37 versus $40 \%$ NFC. As explained by Oelker et al. (2009), LF typically does not decrease ruminal $\mathrm{pH}$ and often increases it, which was observed by Penner et al. (2009), with increased DMI when feeding sucrose. Thus, the potential for enhanced NDF digestibility and DMI when feeding sugars might depend on having less starch digested in the rumen.

The main focus of this research was to determine if adding sugar from a LF product to replace ground corn 
would improve animal performance and digestibility when the corn was coarsely ground (CGC) compared with finely ground (FGC). Steam-flaked corn (SFC) was chosen as a control because of its greater ruminal NSC digestibility.

\section{MATERIALS AND METHODS}

\section{In Situ Evaluation}

An in situ trial with the corn sources was completed before the feeding trials. This project included 3 types of corn grain: SFC, FGC with a mean particle size of $0.8 \mathrm{~mm}$, and CGC with $1.9 \mathrm{~mm}$ (diameter of sieve). Three rumen-cannulated cows fed ad libitum were used with 2 replications per cow. Cows were fed a standard herd diet of about $18 \%$ alfalfa hay, $30 \%$ corn silage, and $52 \%$ concentrate. Dacron bags (10 by $20 \mathrm{~cm}$ and approximately $50 \mu \mathrm{m}$ pore size; Ankom, Fairport, NY) containing 2 (replication 1) or 5 (replication 2) g of corn grain were placed inside the rumen and removed at 2 , 4, 8, 12, 24, 36, and $48 \mathrm{~h}$. Kinetics of DM disappearance were done using the log-linear procedure to obtain initial parameter estimates, followed by iterations using the nonlinear procedures of SAS (SAS Institute, 2004) for lag time, potentially digestible fraction, rate of digestion, and a residue (Firkins, 1997). A rate of passage at $0.05 / \mathrm{h}$ was used for calculation of ruminal degradation.

\section{Diets}

Diets were formulated to be similar except for the type of processing for the corn and with the addition of LF as a source of sugar (Dairy TMR 20; Quality Liquid Feeds, Dodgeville, WI). The control diet consisted of $18.3 \%$ SFC and the other 4 diets consisted of either 18.3 or $15.3 \% \mathrm{FGC}$ or CGC and 0 or $3.5 \%$ $\mathrm{LF}$ in a factorial arrangement (Table 1). The SFC was provided by Pennfield Feeds (Lancaster, PA) and had a measured flake density of $514 \mathrm{~g} / \mathrm{L}$. A flake density of 320 to $390 \mathrm{~g} / \mathrm{L}$ has been recommended (Plascencia and Zinn, 1996) and, thus, the supplier's target density was $321 \mathrm{~g} / \mathrm{L}$. The density was measured at the end of the study in our laboratory, and moisture loss and handling probably increased flake breakage. The FGC and CGC were processed from the same bin of corn harvested in 2007. Diets contained 24\% corn silage and were formulated to contain $16 \%$ alfalfa hay and $6 \%$ grass hay, with proportions of the 2 hay sources adjusted during the trial to maintain a targeted $36 \%$ NDF. Over the course of the trial, alfalfa and grass hay levels averaged 20 and $2 \%$, respectively (Table 1). Diets were formulated to contain $20 \%$ forage NDF and $36 \%$
NFC and similar concentrations of RDP, RUP, MP, minerals, and vitamins to meet NRC (2001) guidelines. The LF from cane molasses and corn steep liquor was $64.5 \% \mathrm{DM}$ and contained $31.2 \% \mathrm{CP}$ and $51.4 \%$ sugar (DM basis). Thus, LF diets were formulated to contain $1.8 \%$ supplemental sugar. Given that the LF contained approximately $22.7 \%$ of DM as CP from NPN, urea was added at $0.28 \%$ of diets without LF. Soybean and blood meals were used to balance for RUP and MP.

\section{Feeding and Sampling}

In experiment 1, 5 rumen-cannulated cows (184 \pm 116 DIM, range 66 to 362 DIM) were fed the 5 diets described previously in a $5 \times 5$ balanced Latin square design. Each period was 2 wk, with d 10 to 13 used for sampling for digestibility measures. Orts were weighed and feed was mixed in the p.m., and cows were fed twice daily for $110 \%$ of ad libitum intake. Samples of TMR and orts were taken daily during the collection period, and feces were sampled so that every $3 \mathrm{~h}$ in a 24-h period were represented (total of 8 samples per period). Chromic oxide pellets ( $88.74 \%$ soybean hulls, $9.26 \%$ chromic oxide, and $2.00 \%$ animal fat, as-is basis) were dosed twice daily ( $50 \mathrm{~g} /$ dose $)$ via rumen cannula during d 3 through 13 . Rumen samples were taken at 3 , 6 , and $9 \mathrm{~h}$ after the a.m. feeding on $\mathrm{d} 12$ and 13 , and $\mathrm{pH}$ was measured immediately. A subsample of the ruminal contents was strained through 4 layers of cheesecloth, and a $50-\mathrm{mL}$ aliquot of the filtered rumen fluid was acidified with $3 \mathrm{~mL}$ of $6 \mathrm{~N} \mathrm{HCl}$ and frozen at $-20^{\circ} \mathrm{C}$ until further analysis of VFA and ammonia.

Cows were housed in a tie-stall barn and were milked twice daily in a parlor. The DMI and milk yield reported were taken from d 10 to 14 of each period. Milk was sampled for 4 consecutive milkings during wk 2 . Body weight was recorded once per period at the same time of day, and cows were scored for BCS at the end of each period. The TMR and orts (weighted based on refusal amounts) samples taken during the collection period were composited by period and dried at $55^{\circ} \mathrm{C}$. After drying at $40^{\circ} \mathrm{C}$, fecal samples for each cow were composited by period.

In experiment 2, 60 Holstein cows were blocked by parity, previous lactation milk yield, and date of calving and assigned to 1 of 12 blocks. Within each block, cows were randomly assigned to 1 of the 5 dietary treatments described previously. Cows began on the trial the nearest Monday to 60 DIM, at which time they were fed a covariate diet for $2 \mathrm{wk}$. The FGC diet without LF was used for the covariate period. After the $2 \mathrm{wk}$, cows were fed their respectively assigned treatment diet for $12 \mathrm{wk}$. Orts were weighed and feed was mixed in the p.m., and cows were fed twice daily for $110 \%$ of ad libitum intake. 
Table 1. Ingredient composition (\% of DM) of diets for experiments 1 and $2^{1}$

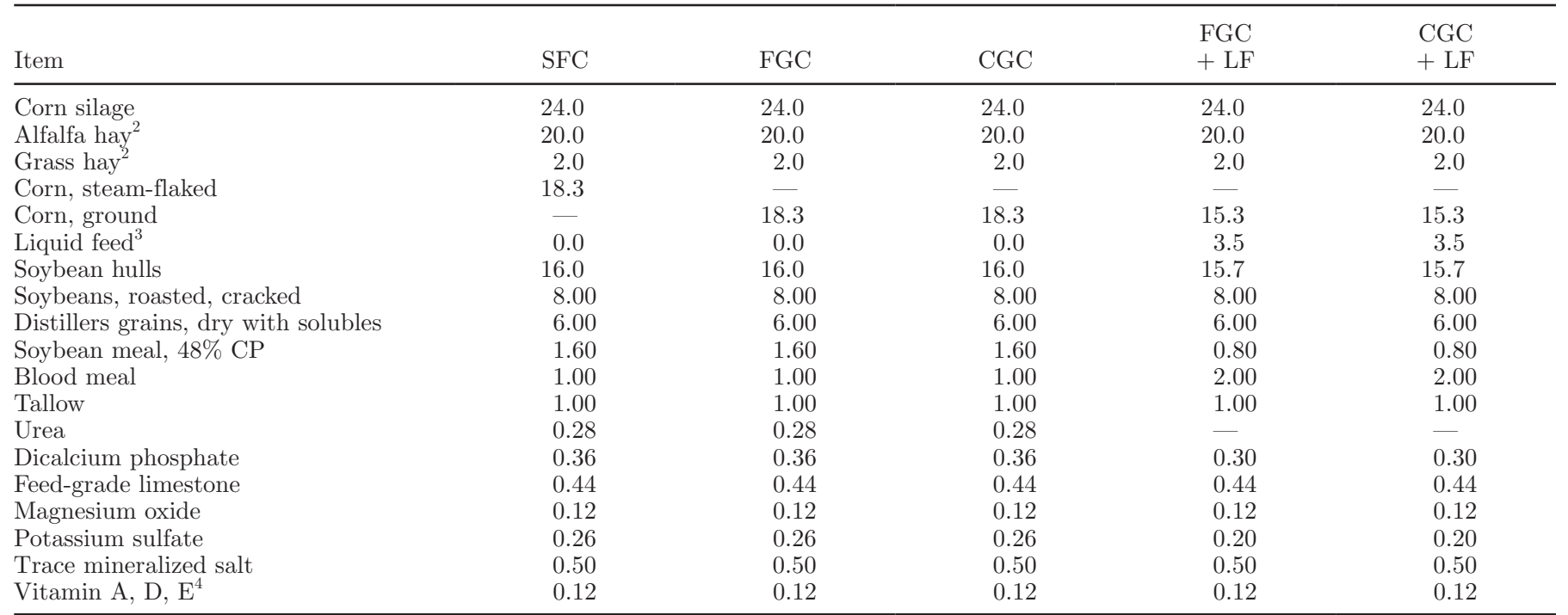

${ }^{1} \mathrm{SFC}=$ Steam-flaked corn, FGC = finely ground corn, CGC = coarsely ground corn, and LF = liquid feed.

${ }^{2}$ Alfalfa and grass hay concentrations were adjusted to maintain a targeted $36 \%$ NDF. Diets were formulated to consist of $16 \%$ alfalfa hay and $6 \%$ grass hay, but average concentrations were as shown.

${ }^{3}$ Sugar source (Dairy TMR 20; Quality Liquid Feeds, Dodgeville, WI).

${ }^{4}$ Provided $0.02 \%$ of dietary DM as a vitamin A premix (30,000 IU/g), 0.04\% vitamin D (3,000 IU/g), and 0.06\% vitamin E (44 IU/g).

Cows were housed in a tie-stall barn and were milked daily at 0500 and $1700 \mathrm{~h}$ in a parlor. Milk was sampled each week for 4 consecutive milkings. Body weight was recorded weekly, and BCS was recorded at the beginning of the covariate and treatment periods and at wk 4,8 , and 12 of the treatment period. For assessment of sorting, the TMR and orts were sampled at wk 4,8 , and 12 from each cow for measurement of particle size using the 3-screen Penn State Particle Separator (Kononoff et al., 2003). A sorting index was calculated for each screen and the pan based on actual versus expected intake of particles (Zebeli et al., 2009). An index value of 1 indicated no sorting, a value $<1$ indicated sorting against, and a value $>1$ indicated sorting in favor of the particles on the respective screen. Weekly samples of TMR were taken and dried at $55^{\circ} \mathrm{C}$ for determination of DMI.

During both experiments, corn silage DM was measured weekly at $55^{\circ} \mathrm{C}$ and ration adjustments made as necessary. Samples of concentrate mixtures were taken weekly and new shipments of SFC were sampled. Monthly samples of corn silage and alfalfa and grass hays were taken for analyses in our laboratory, and periodic samples were sent to the Dairy One Laboratory (Ithaca, NY) from which NDF data (near infrared analysis) were used to adjust subsequent proportions of alfalfa and grass hays to maintain the target of $36 \%$ $\mathrm{NDF}$ in diets.

\section{Laboratory Analyses}

Samples of feed offered, orts, and fecal contents were ground to pass through a 1-mm screen (Wiley Mill, Arthur H. Thomas Co., Philadelphia, PA). Chromic oxide pellets were ground manually using a mortar and pestle. Samples of feed offered, orts, and fecal contents were analyzed for DM, OM, and N (AOAC, 1990). The NDF and ADF concentrations of feed offered, orts and fecal contents were analyzed using an ANKOM 200 fiber analyzer (Ankom Technology, Macedon, NY) based on procedures of Van Soest et al. (1991) using heat-stable $\alpha$-amylase and sodium sulfite. The samples were pre-treated with acetone to remove fat. Chromic oxide pellets and fecal samples were analyzed for $\mathrm{Cr}$ by atomic absorption spectroscopy (Williams et al., 1962). Feed offered was analyzed for mineral concentrations using inductively coupled plasma emission spectrometry by The Ohio State University STAR laboratory (Wooster, OH).

The acidified rumen fluid samples were thawed, centrifuged at $15,000 \times g$ at $4^{\circ} \mathrm{C}$ for $15 \mathrm{~min}$, and filtered through Whatman \#1 filter paper. The supernatant was analyzed for VFA concentrations by GLC (Harvatine et al., 2002) and for concentration of $\mathrm{NH}_{3} \mathrm{~N}$ (Chaney and Marbach, 1962).

Feed offered, orts, and fecal contents in experiment 1 and the corn silage and grain samples from experiment 
2 were analyzed for starch content using an enzymatic procedure utilizing heat-stable $\alpha$-amylase and amyloglucosidase (M. B. Hall, US Dairy Forage Research Center, Madison, WI, personal communication, 2008). The glucose in the starch assay was analyzed colorimetrically using glucose oxidase-peroxidase (Karkalas, 1985). The procedure with modifications was provided by Mathew (2008). The TMR samples in experiment 1 were analyzed for sugars, using the ethanol-soluble carbohydrates procedure described by Hall et al. (1999).

Milk samples were analyzed by DHI Cooperative, Inc. (Columbus, $\mathrm{OH}$ ) for concentrations of fat and protein using infrared spectroscopy (B2000 Infrared Analyzer, Bentley Instruments, Chaska, MN) and MUN using a Skalar SAN Plus segmented flow analyzer (Skalar Inc., Norcross, GA). Milk component percentages were weighted for the amount of milk per milking.

\section{Statistical Analyses}

For experiment 1, data were analyzed as a Latin square design with cow as a random effect, using PROC MIXED of SAS (version 9.1.3; SAS Institute, 2004). The $\mathrm{pH}, \mathrm{VFA}$, and $\mathrm{NH}_{3} \mathrm{~N}$ measurements were analyzed as repeated measures using PROC MIXED, and the compound symmetry covariance structure was used. Diet by time interactions are not discussed because such interactions $(P<0.10)$ occurred only with valerate and isobutyrate.

For experiment 2, data from 54 cows were used instead of 60 as planned. Due to death or health problems unrelated to treatment, some cows were removed, leaving 11 cows per treatment for all treatments except for FGC + LF for which there were 10 cows. Of the cows used for data analysis, 26 were primiparous and 28 were multiparous. Data were analyzed as a randomized complete block design with block as a random effect. Repeated measures (dependent variables by week) were analyzed using PROC MIXED, cow within diet and block as the SUBJECT, and the autoregressive [AR(1)] covariance structure was used for all data except the concentrations of milk components for which compound symmetry was used. No diet by week interactions $(P<$ $0.10)$ occurred except for BW $(P=0.10)$, and this is not discussed given that no differences were observed among treatments for BW change.

Pre-planned orthogonal contrasts were used to compare treatment means: corn processing, $\mathrm{SFC}$ versus ground corn $(\mathrm{SFvGC})=\mathrm{SFC}$ versus FGC, CGC, FGC $+\mathrm{LF}, \mathrm{CGC}+\mathrm{LF}$; particle size $(\mathrm{PS})=\mathrm{FGC}, \mathrm{FGC}+$ $\mathrm{LF}$ versus $\mathrm{CGC}, \mathrm{CGC}+\mathrm{LF} ; \mathrm{LF}=\mathrm{FGC}, \mathrm{CGC}$ versus $\mathrm{FGC}+\mathrm{LF}, \mathrm{CGC}+\mathrm{LF}$; and interaction $\mathrm{LF}$ versus PS. Unless otherwise noted, significant differences were declared at $P \leq 0.05$ and a trend at $P \leq 0.10$.

\section{RESULTS AND DISCUSSION}

In situ data on the 3 types of corn, 2 particle sizes of ground corn and steam-flaked corn, are provided in Table 2. The rapidly degraded A fraction was lowest for CGC and highest for FGC, with SFC being intermediate. The slowly degraded $\mathrm{B}$ fraction was highest for CGC and similar for FGC and SFC. The C pool (undegraded fraction) and rate of degradation were similar among the corn sources. The estimated extent of ruminal degradation was highest for FCG, intermediate for SFC, and lowest for CGC. No lag existed for the SFC, but the ground corn had a lag of about $2.6 \mathrm{~h}$. The 3 corn sources differed in estimated ruminal digestibility characteristics, as expected, to warrant the treatment combinations used in this study.

Chemical composition of the forages and the diets fed in experiments 1 and 2 is provided in Table 3. Composition of the forages used in the study was typical, except that the starch in the corn silage was lower than expected concentrations of 30 to $34 \%$ (Hall and Mertens, 2008; Kung Jr. et al., 2008) and NDF concentration slightly higher than normal in corn silage (45\% NDF; NRC, 2001). The diets averaged $64.7 \% \mathrm{DM}$ and $16.6 \%$ CP. The dietary concentration of NDF was $36.9 \%$, similar to the targeted concentration of $36 \%$, but it ranged from 34.4 to 38.7 in experiment 2 , possibly affected by the length of the trial and some contributions by sampling errors. Starch concentrations in the diets

Table 2. In situ DM digestibility of steam-flaked corn (SFC) and coarsely and finely ground corn (CGC and FGC, respectively) ${ }^{1}$

\begin{tabular}{lcccccc}
\hline Corn grain & $\begin{array}{c}\text { A pool } \\
(\%)\end{array}$ & $\begin{array}{c}\text { B pool } \\
(\%)\end{array}$ & $\begin{array}{c}\text { C pool } \\
(\%)\end{array}$ & $\begin{array}{c}\mathrm{K}_{\mathrm{d}} \\
(/ \mathrm{h})\end{array}$ & $\begin{array}{c}\text { RD } \\
(\%)\end{array}$ & $\begin{array}{c}\text { Lag } \\
(\mathrm{h})\end{array}$ \\
\hline SFC & $11.51^{\mathrm{c}}$ & $85.0^{\mathrm{b}}$ & 3.52 & 0.043 & $50.1^{\mathrm{c}}$ & $0.00^{\mathrm{b}}$ \\
FCG $(0.8 \mathrm{~mm})$ & $15.42^{\mathrm{b}}$ & $83.1^{\mathrm{b}}$ & 1.45 & 0.057 & $53.6^{\mathrm{b}}$ & $2.27^{\mathrm{a}}$ \\
CGC $(1.9 \mathrm{~mm})$ & $6.08^{\mathrm{a}}$ & $91.1^{\mathrm{a}}$ & 2.82 & 0.052 & $43.1^{\mathrm{a}}$ & $2.94^{\mathrm{a}}$ \\
SEM & 1.17 & 1.9 & 1.31 & 0.005 & 0.9 & 0.32 \\
\hline
\end{tabular}

${ }^{\mathrm{a}-\mathrm{c}}$ Means in the same column followed by different superscript letters differ $(P<0.05)$.

${ }^{1} \mathrm{~A}$ pool $=$ rapidly degraded fraction, $\mathrm{B}$ pool $=$ slowly degraded fraction, $\mathrm{C}$ pool $=$ undegraded fraction, $\mathrm{K}_{\mathrm{d}}=$ rate of degradation, and $\mathrm{RD}=$ extent of ruminal degradation. 
Table 3. Chemical composition of diets and forages fed in experiments 1 and $2^{1}$

\begin{tabular}{|c|c|c|c|c|c|}
\hline Item & $\mathrm{SFC}$ & FGC & CGC & $\begin{array}{l}\text { FGC } \\
+\mathrm{LF}\end{array}$ & $\begin{array}{l}\text { CGC } \\
+\mathrm{LF}\end{array}$ \\
\hline \multicolumn{6}{|l|}{ Experiment 1} \\
\hline DM $(\%)$ & 64.5 & 64.5 & 63.5 & 64.1 & 65.4 \\
\hline $\mathrm{CP}(\%)$ & 16.3 & 16.5 & 16.3 & 16.4 & 17.0 \\
\hline $\operatorname{NDF}(\%)$ & 36.3 & 36.1 & 37.6 & 38.2 & 36.6 \\
\hline Starch $(\%)$ & 19.8 & 18.7 & 16.5 & 17.4 & 16.2 \\
\hline Sugars (\%) & 2.37 & 2.65 & 2.57 & 3.60 & 3.67 \\
\hline Ash (\%) & 6.67 & 7.07 & 7.11 & 7.21 & 7.46 \\
\hline $\mathrm{Ca}(\%)$ & 0.80 & 0.79 & 0.81 & 0.80 & 0.91 \\
\hline $\mathrm{P}(\%)$ & 0.30 & 0.31 & 0.31 & 0.31 & 0.32 \\
\hline $\mathrm{K}(\%)$ & 1.31 & 1.32 & 1.36 & 1.39 & 1.43 \\
\hline $\operatorname{Mg}(\%)$ & 0.27 & 0.27 & 0.28 & 0.28 & 0.29 \\
\hline \multicolumn{6}{|l|}{ Experiment 2} \\
\hline $\mathrm{DM}(\%)$ & 65.2 & 64.7 & 63.9 & 65.4 & 65.3 \\
\hline $\mathrm{CP}(\%)$ & 16.2 & 16.3 & 17.0 & 16.7 & 17.4 \\
\hline NDF (\%) & 38.3 & 36.0 & 37.0 & 34.4 & 38.7 \\
\hline $\operatorname{Starch}^{2}(\%)$ & 17.4 & 19.7 & 17.5 & 15.2 & 14.3 \\
\hline \multirow[t]{2}{*}{ Ash (\%) } & 7.08 & 6.45 & 6.94 & 7.03 & 7.10 \\
\hline & \multicolumn{2}{|c|}{ Corn silage } & \multicolumn{2}{|c|}{ Alfalfa hay } & Grass hay \\
\hline DM (\%) & \multicolumn{2}{|c|}{34.0} & \multicolumn{2}{|c|}{90.1} & 91.5 \\
\hline $\mathrm{CP}(\%)$ & \multicolumn{2}{|c|}{6.60} & \multicolumn{2}{|c|}{19.22} & 10.16 \\
\hline $\operatorname{NDF}(\%)$ & \multicolumn{2}{|c|}{48.9} & \multicolumn{2}{|c|}{39.3} & 63.2 \\
\hline Starch $(\%)$ & \multicolumn{2}{|c|}{20.2} & \multicolumn{2}{|c|}{ - } & - \\
\hline
\end{tabular}

were slightly lower than expected, partially caused by the lower-than-typical starch concentration in corn silage. The starch concentration was lower in the LF diets because the LF replaced corn in the diets. Non-LF diets contained $2.53 \%$ sugars. Although LF diets were assumed to contain $1.8 \%$ supplemental sugars based on analysis of sugars in LF batches, the LF diets provided $1.03 \%$ supplemental sugar.

\section{Experiment 1}

Finer particle size of corn decreased rumen $\mathrm{pH}$ compared with CGC (Table 4); however, ruminal pH averaged about 6 , at or above where animal health or performance would be expected to be affected. The sugar addition using LF had no effect on ruminal $\mathrm{pH}$, a similar response to that reported in other studies (Heldt et al., 1999; Broderick et al., 2008; Oelker et al., 2009). Finer particle sizes (FGC versus CGC) and SFC versus ground corn decreased ruminal $\mathrm{NH}_{3} \mathrm{~N}$ concentrations. The greater extent of ruminal degradation of the FGC and SFC likely allowed for more $\mathrm{NH}_{3} \mathrm{~N}$ assimilation by bacteria. Increasing the level of steam-rolled corn by displacement of coarsely ground corn linearly decreased ruminal $\mathrm{NH}_{3} \mathrm{~N}$ concentration, but decreasing particle size of dry corn did not yield similar results (Callison et al., 2001). Ruminal $\mathrm{NH}_{3} \mathrm{~N}$ concentration was higher with cracked versus ground corn and ground corn plus whey permeate (lactose source; Charbonneau et al.,
2006). Diets had no effects on total VFA concentration and proportion of acetate in the rumen. The FGC and SFC tended to increase ruminal propionate and decrease the acetate:propionate ratio, reflective of the greater extent of ruminal degradation than with CGC. The LF increased molar percentage of butyrate in the rumen and this response occurred more with FGC than CGC, resulting in an interaction of particle size and corn processing. Increased molar percentage of ruminal butyrate with feeding supplemental sugar has been observed in some studies when feeding over $25 \%$ corn silage in diets (Maiga et al., 1995; DeFrain et al., 2006; Golombeski et al., 2006), but this has not occurred in other studies with added sugar in diets containing 21 to $44 \%$ corn silage (Broderick et al., 2008; Firkins et al., 2008; Oelker et al., 2009). Yet, Charbonneau et al. (2006) observed an increase in ruminal butyrate when $10.6 \%$ whey permeate was fed in alfalfa silage-based diets compared with feeding cracked or ground corn. The increased butyrate is reflective of increased availability of rapidly degradable NFC, with more lactate production and subsequent fermentation to butyrate (Firkins et al., 2006). Thus, this shift in ruminal fermentation to increased butyrate is independent of ruminal $\mathrm{pH}$, as reflected in our study and reported by others (Ribeiro et al., 2005). Although DeFrain et al. (2006) observed the feeding of $15.8 \%$ lactose to increase ruminal butyrate and plasma BHBA during early lactation, no negative effects on lactation performance occurred. Isobutyrate 
Table 4. Mean rumen $\mathrm{pH}, \mathrm{NH}_{3} \mathrm{~N}$, and VFA in experiment 1 from cows fed steam-flaked corn and 2 particle sizes of ground corn with and without a sugar source

\begin{tabular}{|c|c|c|c|c|c|c|c|c|c|c|}
\hline \multirow[b]{2}{*}{ Item } & \multicolumn{5}{|c|}{ Diet $^{1}$} & \multirow[b]{2}{*}{ SEM } & \multicolumn{4}{|c|}{ Contrast $^{2}$} \\
\hline & $\mathrm{SFC}$ & FGC & CGC & $\begin{array}{l}\text { FGC } \\
+\mathrm{LF}\end{array}$ & $\begin{array}{l}\text { CGC } \\
+\mathrm{LF}\end{array}$ & & SFvGC & PS & $\mathrm{LF}$ & $\begin{array}{c}\text { PS } \\
\times \mathrm{LF}\end{array}$ \\
\hline $\mathrm{pH}$ & 6.03 & 6.04 & 6.20 & 5.94 & 6.12 & 0.11 & 0.59 & 0.03 & 0.24 & 0.87 \\
\hline $\mathrm{NH}_{3} \mathrm{~N}(\mathrm{mg} / \mathrm{dL})$ & 9.28 & 10.18 & 12.28 & 11.17 & 11.53 & 1.74 & $<0.01$ & 0.04 & 0.84 & 0.14 \\
\hline Total VFA $(\mathrm{m} M)$ & 146 & 145 & 140 & 150 & 143 & 5 & 0.81 & 0.16 & 0.31 & 0.76 \\
\hline \multicolumn{11}{|c|}{ VFA profile $(\mathrm{mol} / 100 \mathrm{~mol})$} \\
\hline Butyrate & 10.9 & 10.4 & 11.0 & 11.7 & 11.2 & 0.2 & 0.29 & 0.49 & $<0.01$ & $<0.01$ \\
\hline Isobutyrate & 0.69 & 0.71 & 0.75 & 0.68 & 0.74 & 0.06 & 0.24 & 0.03 & 0.33 & 0.71 \\
\hline Valerate & 1.40 & 1.33 & 1.34 & 1.42 & 1.38 & 0.04 & 0.30 & 0.52 & 0.02 & 0.30 \\
\hline Isovalerate & 1.29 & 1.18 & 1.27 & 1.21 & 1.26 & 0.15 & 0.39 & 0.25 & 0.84 & 0.73 \\
\hline Acetate:propionate & 3.17 & 3.24 & 3.46 & 3.34 & 3.42 & 0.18 & 0.05 & 0.09 & 0.75 & 0.42 \\
\hline
\end{tabular}

${ }^{1} \mathrm{SFC}=$ steam-flaked corn, FGC = finely ground corn, CGC = coarsely ground corn, and LF = liquid feed.

${ }^{2} \mathrm{SFvGC}=$ corn processing, steam-flaked versus ground corn (SFC vs. FGC, CGC, FGC + LF, CGC + LF); PS = particle size $($ FGC, FGC + $\mathrm{LF}$ vs. CGC, CGC + LF); LF = liquid feed $(\mathrm{FGC}, \mathrm{CGC}$ vs. FGC + LF, CGC + LF); and PS $\times$ LF $=$ interaction of particle size and liquid feed

was higher with CGC compared with FGC, and LF addition elevated ruminal valerate.

Although experiment 1 was designed primarily as a digestibility trial, animal performance data are provided in Table 5. The DMI was similar among diets, averaging $24.6 \mathrm{~kg} / \mathrm{d}$. Milk yield exceeded $36 \mathrm{~kg} / \mathrm{d}$ and typical concentrations of milk fat and protein for Holstein cows occurred. These data will be discussed in conjunction with the data from experiment 2 ; however, it also is acknowledged that cows were 184 versus 60 DIM for experiment 1 and 2 , respectively.

Total tract apparent digestibilities of $\mathrm{OM}, \mathrm{N}$, and NDF were not affected by dietary treatment (Table 6). Even if NDF digestibility was lower in the rumen because of the slightly lower ruminal $\mathrm{pH}$ (Firkins et al., 2001) with FGC, sufficient compensatory hindgut digestion occurred, whereby the total tract digestion of NDF was unaffected. Callison et al. (2001) noted a ten- dency $(P=0.14)$ for a linear decrease in ruminal NDF digestibility with a decrease in corn grain particle size $(4.8,2.6$, and $1.2 \mathrm{~mm})$, but total tract NDF digestibility was unaffected. Thus, even with our lower particle size for FGC $(0.8 \mathrm{~mm})$ compared with that of Callison et al. (2001), NDF digestibilities for FGC and CGF were similar. The LF tended to decrease total tract starch digestibility, primarily with the CGC. The sugar may have provided a rapidly available energy source for bacteria, decreasing the degradation of starch from CGC before it passed out of the rumen. When feeding barley silage-based diets $(\sim 40 \%)$ and dietary starch concentrations similar to those in our study, sucrose addition at 4.4 to $4.7 \%$ (5.7 to $8.7 \%$ total sugar, respectively) had no effect on total tract starch digestibility (Penner and Oba, 2009; Penner et al., 2009). However, the starch from the barley silage and grain fed may have been more rapidly degraded in the rumen than

Table 5. The DMI, lactation performance, and milk composition for cows in experiment 1 fed steam-flaked corn and 2 particle sizes of ground corn with and without a sugar source

\begin{tabular}{|c|c|c|c|c|c|c|c|c|c|c|}
\hline \multirow[b]{2}{*}{ Item } & \multicolumn{5}{|c|}{$\operatorname{Diet}^{1}$} & \multirow[b]{2}{*}{ SEM } & \multicolumn{4}{|c|}{ Contrast $^{2}$} \\
\hline & $\mathrm{SFC}$ & FGC & CGC & $\begin{array}{l}\text { FGC } \\
+\mathrm{LF}\end{array}$ & $\begin{array}{l}\text { CGC } \\
+\mathrm{LF}\end{array}$ & & SFvGC & PS & $\mathrm{LF}$ & $\begin{array}{c}\mathrm{PS} \\
\times \mathrm{LF}\end{array}$ \\
\hline $\mathrm{BW}(\mathrm{kg})$ & 791 & 783 & 780 & 782 & 789 & 23 & 0.42 & 0.82 & 0.59 & 0.59 \\
\hline $\mathrm{BCS}$ & 2.75 & 2.65 & 2.60 & 2.50 & 2.65 & 0.13 & 0.10 & 0.52 & 0.52 & 0.52 \\
\hline Milk (kg/d) & 38.0 & 36.1 & 35.7 & 36.0 & 35.9 & 7.7 & 0.10 & 0.84 & 0.95 & 0.87 \\
\hline Milk protein (\%) & 2.87 & 2.84 & 2.97 & 2.77 & 2.78 & 0.11 & 0.73 & 0.31 & 0.07 & 0.37 \\
\hline Milk protein $(\mathrm{kg} / \mathrm{d})$ & 1.09 & 1.02 & 1.03 & 0.99 & 1.01 & 0.21 & 0.01 & 0.63 & 0.27 & 0.26 \\
\hline MUN (mg/dL) & 11.8 & 11.7 & 13.3 & 11.9 & 12.6 & 1.0 & 0.34 & 0.04 & 0.58 & 0.37 \\
\hline
\end{tabular}

${ }^{1} \mathrm{SFC}=$ steam-flaked corn, $\mathrm{FGC}=$ finely ground corn, $\mathrm{CGC}=$ coarsely ground corn, and LF = liquid feed.

${ }^{2} \mathrm{SFvGC}=$ corn processing, steam-flaked versus ground corn (SFC vs. FGC, CGC, FGC + LF, CGC + LF); PS = particle size (FGC, FGC + $\mathrm{LF}$ vs. CGC, CGC + LF); LF = liquid feed (FGC, CGC vs. FGC + LF, CGC + LF); and PS $\times$ LF = interaction of particle size and liquid feed. 
Table 6. Apparent total tract digestibilities for cows in experiment 1 fed steam-flaked corn and 2 particle sizes of ground corn with and without a sugar source

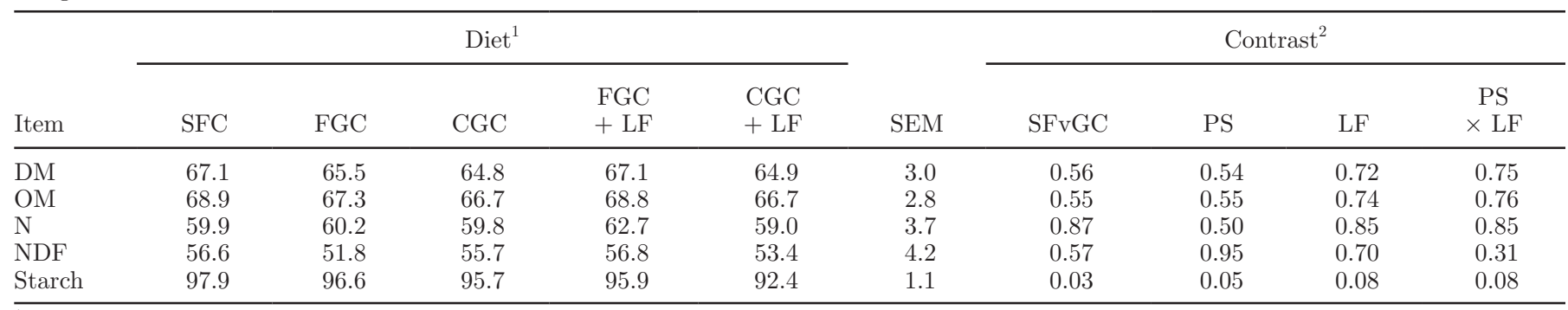

${ }^{1} \mathrm{SFC}=$ steam-flaked corn, $\mathrm{FGC}=$ finely ground corn, $\mathrm{CGC}=$ coarsely ground corn, and LF = liquid feed.

${ }^{2} \mathrm{SFvGC}=$ corn processing, steam-flaked versus ground corn (SFC vs. FGC, CGC, FGC + LF, CGC + LF); PS = particle size (FGC, FGC + LF vs. CGC, CGC + LF); LF = liquid feed (FGC, CGC vs. FGC + LF, CGC + LF); and PS $\times$ LF $=$ interaction of particle size and liquid feed.

with starch in the corn silage and CGC in our study. The FGC slightly increased starch digestibility because of the greater surface area for bacterial and enzyme access to the starch granules. The SFC resulted in only a slight increase in total tract digestibility of starch. Most of these differences in starch digestibility were caused by the lower starch digestibility with CGC. Callison et al. (2001) observed total tract NSC digestibility to linearly decrease with increasing corn particle size (1.2, 2.6 , and $4.8 \mathrm{~mm}$ ). Our data supports their conclusion that a mean particle size for ground corn of $\leq 1.0 \mathrm{~mm}$ seems to be needed to maximize total tract NSC digestibility.

\section{Experiment 2}

As in experiment 1 , dietary treatment had no effect on DMI, averaging $25.8 \mathrm{~kg} / \mathrm{d}$ (Table 7). Although LF tended to decrease BCS, no difference among treat- ments was observed for changes in BCS and BW; thus, this observance with LF is likely of little physiological significance. Milk yield averaged $39.7 \mathrm{~kg} / \mathrm{d}$ and was similar among treatments. Yu et al. (1998) observed that cows fed diets with SFC at a medium density (361 $\mathrm{g} / \mathrm{L}$ ) had increased milk yield compared with those fed finely or coarsely ground corn. However, alfalfa hay was the forage source in their study compared with corn silage being the primary forage in our trial.

Milk fat percentage tended to be lower and milk fat yield was decreased with SFC compared with ground corn, aligning with ruminal conditions that increase ruminal propionate and lower acetate:propionate ratio (Table 4). This response in milk fat resulted in a lower $3.5 \%$ FCM with feeding SFC. The lower FCM with similar DMI resulted in a lower feed efficiency (FCM/ DMI) with the SFC. In experiment 1 , milk fat yield tended to be higher with SFC because of the tendency for milk yield to be higher with SFC. Additional ani-

Table 7. The DMI and animal performance by cows in experiment 2 fed steam-flaked corn and 2 particle sizes of ground corn with and without a sugar source

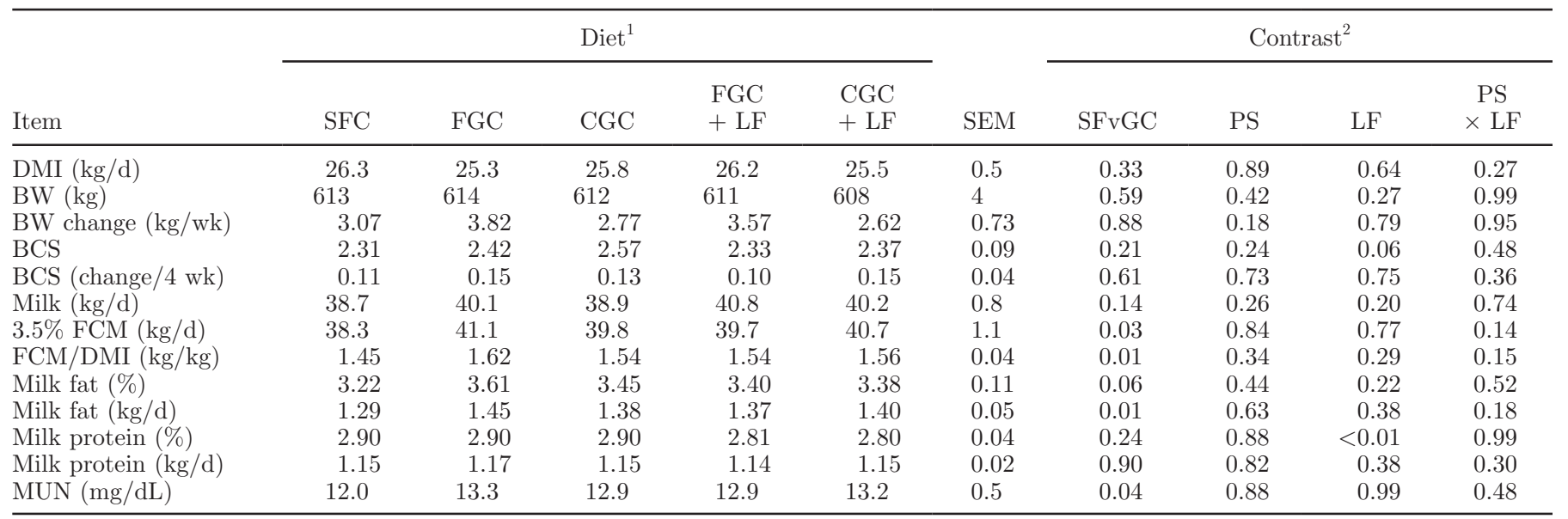

${ }^{1} \mathrm{SFC}=$ steam-flaked corn, $\mathrm{FGC}=$ finely ground corn, $\mathrm{CGC}=$ coarsely ground corn, and $\mathrm{LF}=$ liquid feed.

${ }^{2} \mathrm{SF}$ vGC $=$ corn processing, steam-flaked versus ground corn (SFC vs. FGC, CGC, FGC + LF, CGC + LF); PS = particle size (FGC, FGC + LF vs. CGC, CGC + LF); LF = liquid feed $(F G C, C G C$ vs. FGC + LF, CGC + LF); and PS $\times$ LF $=$ interaction of particle size and liquid feed. 


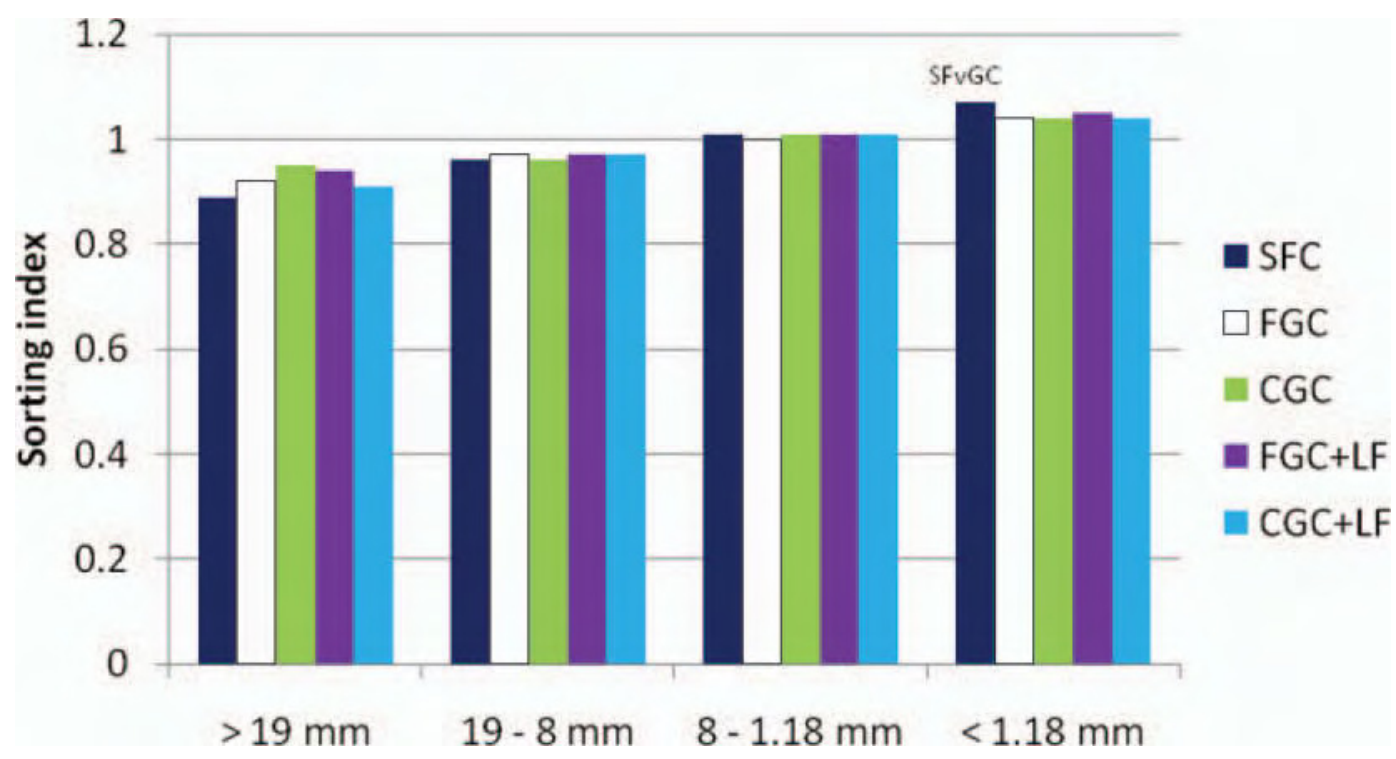

Figure 1. Sorting index $(1=$ no sorting, $<1=$ sorting against, and $>1=$ sorting in favor $)$ for cows in experiment 2 fed steam-flaked corn and 2 particle sizes of ground corn with and without a sugar source. SFC = steam-flaked corn; FGC = finely ground corn; CGC $=$ coarsely ground corn; LF = liquid feed; SFvGC = corn processing, steam-flaked versus ground corn (SFC vs. FGC, CGC, FGC + LF, CGC + LF), $P<0.01$. Color version available in the online PDF.

mals in a similar stage of lactation and diets fed for longer duration provide more credence to the animal performance observations in experiment 2 . In both experiments, milk protein percentage was decreased with LF, but milk protein yield was not affected. A decrease in milk protein percentage with sugar addition in corn silage-based diets was observed by Maiga et al. (1995) and Firkins et al. (2008), but the level and source of sugar had no separate effects on milk protein percentage. Others feeding barley silage (Penner and Oba, 2009; Penner et al., 2009), 40\% alfalfa silage (Broderick et al., 2008), or corn silage- or alfalfa hay- (Oelker et al., 2009) based diets observed no effects of sugar addition on milk protein percentage. Diets were formulated for similar fractions of RDP, RUP, and MP, and urea was added to diets without LF because of the NPN in the LF. Ruminal $\mathrm{NH}_{3} \mathrm{~N}$ (Table 4) and MUN (Tables 5 and 7) concentrations do not reflect more RDP or an inability for bacteria to capture the degraded $\mathrm{N}$ in the LF diets. Possibly, the lower dietary starch levels, thus potential change in the rate of NFC degradation, with the LF had an effect on microbial protein synthesis in the rumen. However, the decrease in milk protein percentage observed by Firkins et al. (2008) occurred with 38 or $40 \%$ NFC (21 or $24 \%$ starch). Although milk protein yield was higher with SFC in experiment 1 , this was not observed in the production-based trial. The FGC decreased MUN content compared with CGC in experiment 1 (Table 4), and SFC compared with ground corn decreased MUN content in experiment 2 (Table 7), each reflective of the higher ruminal starch availability providing for possible improvement in the bacterial capture of the N. For example, Callison et al. (2001) observed a decrease in duodenal flow of ammonia $\mathrm{N}$ with decreasing particle size and steam rolling of corn.

The SFC diet compared with ground corn diets resulted in more particles on the 19- to 8-mm screen (31.3 vs. $24.8 \%$; data not shown) because of the larger corn particles; thus, the SFC diet had fewer particles on the $<1.18$-mm screen (23.1 vs. $28.7 \%$ ). Cows selected for the smaller $(<1.18-\mathrm{mm})$ particles in the SFC diet compared with the ground corn diets (Figure 1). Using LF has been purported to be beneficial in decreasing the risks for sorting of the TMR, especially when TMR are high in DM, such as in this study. In addition, adding water to silage and high-moisture corn-based diets has been reported to increase the risk for sorting (MillerCushon and DeVries, 2009); thus, in such situations, LF may be assumed to be a favorable option for decreasing sorting risk. The LF increased the number of particles $>19 \mathrm{~mm}$ for FGC but not the CGC diets and tended to increase the number of particles on the $<1.18-\mathrm{mm}$ screen with CGC but not the FGC diet. Oelker et al. (2009) observed the addition of sugar as molasses to increase the proportion of particles 8 to $19 \mathrm{~mm}$ and decrease particles $<8 \mathrm{~mm}$ in corn silage-based diets but not with alfalfa hay-based diets, suggesting that sugar in LF may help to conglomerate small particles in TMR. No effect of LF on the orts was observed, and thus, we did not observe any effect of LF on the sorting index (Figure 1). In contrast to our study, Penner and 
Oba (2009) observed the addition of sugar as sucrose to increase the sorting for small particles $(<8 \mathrm{~mm})$. As expected, some sorting occurred among all diets against the larger particles, with the sorting index increasing as particle size decreased (Figure 1).

\section{CONCLUSIONS}

In conclusion, we could not accept our hypothesis that the sugars found in the LF would maintain or improve measures of ruminal fermentation and diet digestibility to a greater degree when corn is coarsely ground compared with finely ground. However, the SFC and FGC may have been more rapidly fermented in the rumen, without adversely affecting DMI or NDF digestibility. The LF appeared to be more beneficial with the FGC than the CGC diets. The LF could possibly serve as an alternate method of increasing ruminal fermentation of FGC compared with feeding SFC. The results of this study emphasize the importance of smaller particle size of corn $(<1.0 \mathrm{~mm})$ for optimizing ruminal fermentation and total tract starch digestibility, thus possibly improving animal performance and efficiency of nutrient utilization.

\section{REFERENCES}

AOAC. 1990. Official Methods of Analysis. Vol. I. 15th ed. Association of Official Analytical Chemists, Arlington, VA.

Broderick, G. A., N. D. Luchini, S. M. Reynal, G. A. Varga, and V. A. Ishler. 2008. Effect on production of replacing dietary starch with sucrose in lactating dairy cows. J. Dairy Sci. 91:4801-4810.

Broderick, G. A., and W. J. Radloff. 2004. Effect of molasses supplementation on the production of lactating dairy cows fed diets based on alfalfa and corn silage. J. Dairy Sci. 87:2997-3009.

Callison, S. L., J. L. Firkins, M. L. Eastridge, and B. L. Hull. 2001. Site of nutrient digestion by dairy cows fed corn of different particle sizes or steam-rolled. J. Dairy Sci. 84:1458-1467.

Chaney, A. L., and E. P. Marbach. 1962. Modified reagents for determination of urea and ammonia. Clin. Chem. 8:130-132.

Charbonneau, E., P. Y. Chouinard, G. Allard, H. Lapierre, and D. Pellerin. 2006. Milk from forage as affected by carbohydrate source and degradability with alfalfa silage-based diets. J. Dairy Sci. 89:283-293.

DeFrain, J. M., A. R. Hippen, K. F. Kalscheur, and D. J. Schingoethe. 2006. Feeding lactose to increase ruminal butyrate and the metabolic status of transition dairy cows. J. Dairy Sci. 89:267-276.

Firkins, J. L. 1997. Effects of feeding nonforage fiber sources on site of fiber digestion. J. Dairy Sci. 80:1426-1437.

Firkins, J. L., M. L. Eastridge, N. R. St-Pierre, and S. M. Noftsger. 2001. Effects of grain variability and processing on starch utilization by lactating dairy cattle. J. Anim. Sci. 79 (E Suppl.):E218E238.

Firkins, J. L., A. N. Hristov, M. B. Hall, G. A. Varga, and N. R. StPierre. 2006. Integration of ruminal metabolism in dairy cattle. J. Dairy Sci. 89 (E. Suppl.):E31-E51.

Firkins, J. L., B. S. Oldick, J. Pantoja, C. Reveneau, L. E. Gilligan, and L. Carver. 2008. Efficacy of liquid feeds varying in concentration and composition of fat, nonprotein nitrogen, and nonfiber carbohydrates for lactating dairy cows. J. Dairy Sci. 91:1969-1984.

Golombeski, G. L., K. F. Kalscheur, A. R. Hippen, and D. J. Schingoethe. 2006. Slow-release urea and highly fermentable sugars in diets fed to lactating dairy cows. J. Dairy Sci. 89:4395-4403.
Hall, M. B., W. H. Hoover, J. P. Jennings, and T. K. Miller-Webster. 1999. A method for partitioning neutral detergent fiber soluble carbohydrates. J. Sci. Food Agric. 79:2079-2086.

Hall, M. B., and D. R. Mertens. 2008. Technical note: Effect of sample processing procedures on measurement of starch in corn silage and corn grain. J. Dairy Sci. 91:4830-4833.

Harvatine, D. I., J. L. Firkins, and M. L. Eastridge. 2002. Whole linted cottonseed as a forage substitute fed with ground or steam-flaked corn: Digestibility and performance. J. Dairy Sci. 85:1976-1987.

Heldt, J. S., R. C. Cochran, G. L. Stokka, C. G. Farmer, C. P. Mathis, E. C. Titgemeyer, and T. G. Nagaraja. 1999. Effects of different supplemental sugars and starch fed in combination with degradable intake protein on low-quality forage use by beef steers. J. Anim. Sci. 77:2793-2802.

Karkalas, J. J. 1985. An improved enzymatic method for the determination of native and modified starch. J. Sci. Food Agric. 36:1019-1027.

Kononoff, P. J., A. J. Heinrichs, and D. R. Buckmaster. 2003. Modification of the Penn State forage and total mixed ration particle separator and the effects of moisture content on its measurements. J. Dairy Sci. 86:1858-1863.

Kung, L. Jr., B. M. Moulder, C. M. Mulrooney, R. S. Teller, and R. J. Schmidt. 2008. The effect of silage cutting height on the nutritive value of a normal corn silage hybrid compared with brown midrib corn silage fed to lactating cows. J. Dairy Sci. 91:1451-1457.

Maiga, H. A., D. J. Schingoethe, and F. C. Ludens. 1995. Evaluation of diets containing supplemental fat with different sources of carbohydrates for lactating dairy cows. J. Dairy Sci. 78:1122-1130.

Mathew, B. 2008. Interactions of monensin with dietary fat and carbohydrate components on ruminal fermentation and production responses by dairy cows. MS Thesis. The Ohio State University, Columbus.

Miller-Cushon, E. K., and T. J. DeVries. 2009. Effect of dietary dry matter concentration on the sorting behavior of lactating dairy cows fed a total mixed ration. J. Dairy Sci. 92:3292-3298.

NRC. 2001. Nutrient Requirements of Dairy Cattle. 7 rev. ed. Natl. Acad. Sci., Washington, DC.

Oelker, E. R., C. Reveneau, and J. L. Firkins. 2009. Interaction of molasses and monensin in alfalfa hay- or corn silage-based diets on rumen fermentation, total tract digestibility, and milk production by Holstein cows. J. Dairy Sci. 92:270-285.

Penner, G. B., L. L. Guan, and M. Oba. 2009. Effects of feeding Fermenten on ruminal fermentation in lactating Holstein cows fed two dietary sugar concentrations. J. Dairy Sci. 92:1725-1733.

Penner, G. B., and M. Oba. 2009. Increasing dietary sugar concentration may improve dry matter intake, ruminal fermentation, and productivity of dairy cows in the postpartum phase of the transition period. J. Dairy Sci. 92:3341-3353.

Plascencia, A., and R. A. Zinn. 1996. Influence of flake density on the feeding value of steam-processed corn in diets for lactating cows. J. Anim. Sci. 74:310-316.

Ribeiro, C. V. D. M., S. K. R. Karnati, and M. L. Eastridge. 2005. Biohydrogenation of fatty acids and digestibility of fresh alfalfa or alfalfa hay plus sucrose in continuous culture. J. Dairy Sci. 88:4007-4017.

SAS Institute. 2004. SAS/STAT 9.1 User's Guide. SAS Inst. Inc., Cary, NC.

Van Soest, P. J., J. B. Robertson, and B. A. Lewis. 1991. Methods for dietary fiber, neutral detergent fiber, and nonstarch polysaccharides in relation to animal nutrition. J. Dairy Sci. 74:3583-3597.

Williams, C. H., D. J. David, and O. Iismaa. 1962. The determination of chromic oxide in faeces samples by atomic absorption spectrophotometry. J. Agric. Sci. 59:381-385.

Yu, P., J. T. Huber, F. A. P. Santos, J. M. Simas, and C. B. Theurer. 1998. Effects of ground, steam-flaked, and steam-rolled corn grains on performance of lactating cows. J. Dairy Sci. 81:777-783.

Zebeli, Q., B. N. Ametaj, B. Junck, and W. Drochner. 2009. Maize silage particle length modulates feeding patterns and milk composition in loose-housed lactating Holstein cows. Livest. Sci. 124:33-40. 